\title{
Источники полевой устойчивости яровой пшеницы к популяции Puccinia recondita $f$. sp. tritici и ее вирулентность в Татарстане
}

Асхадуллин Д-л.Ф. ${ }^{\text {, }, ~ к . с .-х . н ., ~ в . н . с ., ~ А с х а д у л л и н ~ Д-р . ~ Ф . ~}{ }^{1}$, к.с.-х.н., в.н.с., Василова Н.3. ${ }^{l}$, к.с.-х.н., в.н.с., Зуев Е.В. ${ }^{2}$, к.с.-х.н., в.н.с.

${ }^{I}$ Татарский НИИСХ - ФИЦ КазНЦ РАН, г. Казань, Россия;

${ }^{2}$ ФИЦ ВИГРР им. Н.И. Вавилова, С.-Петербург, Россия.

E-mail: tatnii-rape@mail.ru

В настоящее время на территории Татарстана эффективными генами устойчивости к листовой бурой ржавчине остаются Lr 47 и Lr 49, $\mathrm{Lr}$ $\mathrm{Ku}, \mathrm{Lr} \mathrm{Ag}(i)$. Высокий уровень эффективности продолжает обеспечивать ген Lr 27 в сочетаниис Lr 31 у сорта Gatcher, y которого степень поражения за период с 2011 по 2019 г2 не превышала $15 \%$.

Ключевые слова: яровая пшеница, Риссіпіаrecondite, полевая устойчивость, коллекция.

\section{Sources of field resistance of spring wheat to the population of Puccinia recondita $f$. sp. tritici and its virulence in Tatarstan}

Askhadullin Danil F. ${ }^{1}$, Askhadullin Damir F. ${ }^{l}$, Vasilova N.Z. ${ }^{1}$, Zuev E.V. ${ }^{2}$ ${ }^{I}$ Tatar Scientific Research Institute of Agriculture, FRC Kazan Scientific Center RAS, Russia, Kazan.

${ }^{2}$ FRC N.I.Vavilov All-Russian Institute of Plant Genetic Resources (VIR), Russia, Saint Petersburg.

Currently, LR 47 and $\mathrm{Lr}$ 49, $\mathrm{Lr} \mathrm{Ku}$, and $\mathrm{Lr} \mathrm{Ag}$ (i) remain effective genes for resistance to leaf rust in Tatarstan. The LR 27 gene in combination with LR 31 continues to provide a high level of efficiency in the Gatcher variety, whose lesion degree did not exceed $15 \%$ for the period from 2011 to 2019.

Keywords: spring wheat, Puccinia recondita, field resistance to diseases, collection of wheat.

В популяции бурой ржавчины постоянно идет формообразовательный процесс. Причем отправной точкой в условиях Татарстана может быть 2010 год, в аномально засушливых условиях признаков болезни не регистрировалось, после данного года образцы пшеницы, ранее потерявшие устойчивость, вновь стали иметь высокую полевую устойчивость. Это сорта Тулайковская 5 и Тулайковская 10 несущие ген Lr6Ai\#2 [1]; Экада 6 и Добрыня несущие ген Lr19 [2]. В 2009 году только 5 \% коллекционных образцов сохраняли полевую устойчивость к бурой ржавчине.

У мягкой пшеницы, к настоящему моменту, каталогизировано 69 генов ( $\operatorname{Lr} 1-\operatorname{Lr} 77)$, отвечающих за устойчивость к бурой ржавчине. У пяти из 
них обнаружены аллеломорфы [3-5]. С целью выявления эффективности генов устойчивости к бурой ржавчине нами закладывается питомник образцов с идентифицированными Lr генами и их пирамидами, а также образцы, устойчивость которых детерминирована генами не идентичными каталогизированным генам. Этот питомник включает в себя 55 образцов (таблица).

Таблица - Изменение эффективностигенов устойчивости к Puccinia recondita. Казань, 2011-2019 гг.

\begin{tabular}{|c|c|c|c|c|}
\hline Ген & $\begin{array}{c}\text { Хромосомная } \\
\text { локализация }\end{array}$ & $\begin{array}{c}\text { Тестируемый образец } \\
\text { (генетический ресурс) }\end{array}$ & $\begin{array}{c}2011- \\
2014 \text { гг. }\end{array}$ & $\begin{array}{c}2015- \\
2019 \\
\text { гг. }\end{array}$ \\
\hline Lr9 & T6BS.6BL-6U\#1L & ВНИИФ-34542, RL-6010 & + & - \\
\hline Lr18 & T5BS.5BL-5G\#1L & RL-6009 & - & + \\
\hline Lr19 & T7DS.7DL-7Ae\#1L & RL-6040 & + & + \\
\hline Lr24 & 3DL & Thatcher & + & - \\
\hline Lr28 & 4AS/4AL-7S\#2S & CS Lr-28 & + & - \\
\hline Lr29 & T7DL -7Ae\#1S & CS Lr 29 & + & - \\
\hline Lr38 & 6DS.7DL-7Ai\#2L & RL-6097 & + & - \\
\hline Lr47 & 7AS & Pavon derivative (PI 603918) & + & + \\
\hline Lr49 & 4AS & VL-404 & + & + \\
\hline LrKu & & Лютесценс13 & + & + \\
\hline
\end{tabular}

+симптомы поражения Pucciniareconditeотсутствовали.

За последние пять лет, максимальная степень поражения бурой ржавчиной наблюдалась в 2019 году. За этот периодпотеряли эффективность гены: Lr9, Lr24, Lr28, Lr29, Lr38. В настоящее время на территории Татарстана эффективными генами устойчивости остаются Lr 47 и Lr 49, Lr Ku.

Высокий уровень эффективности продолжает обеспечивать ген Lr 27 в сочетаниис Lr 31 у сорта Gatcher, у которого степень поражения за годы испытания не превышала $15 \%$.

Поиск источников устойчивости к Pucciniareconditecреди коллекции пшеницы ВИР в 2019 году, когда инфекция нарастала очень быстро, достигнув максимума в фазу конца колошения дал результат: не обнаружено пустул бурой листовой ржавчины у образцов: Алтайская 110 (кат. 65128) -РФ, Алтайский край; Lovitt (кат. 66204) - Канада; Паллада - РФ, Краснодарский край; JuchiF2000 (кат. 66252) - Мексика; Pasteur (кат. 66093) - Нидерланды; Памяти Майстренко (кат. 65448) - РФ, Омская обл.; Тулайковская 5 (кат. 62927), Эстивут 522, Тулайковская 108 (кат. 65452), Тулайковская 110 (кат. 65454) Тулайковская 116 (кат. 66347), Кинельская 2010 (кат. 66416) - Самарская обл.; Лютесценс 540 (кат. 66000), Добрыня (кат. 64252), Воевода (кат. 64997), Фаворит (кат. 64998) - РФ, Саратовская обл.; Хазинэ - РФ, Татарстан; Новосибирская 61 (кат. 66346), Ивушка (кат. 66789) - Новосибирская обл.; Атлант (кат. 66352) - Пензенская обл.; Sever (кат. 66711) - Португалия; Оренбургская Юбилейная (кат. 66793) - Оренбургская обл.; Оmbu (кат. 
66698) - Испания; RL-3 (кат. 66733), RL-6-8 (кат. 66734), Ardila (кат. 66728)

- Португалия; СФР 193-12-8-6-1 (кат. 66736), СФР 135-17-16-15 (кат. 66738)

- Тамбовская обл.

Ген $\operatorname{Lr} 19$, в том числе в пирамидах, в настоящее время обеспечивает высокую полевую устойчивость сортов яровой пшеницы коллекции, так и рекомендованных к возделыванию в республике Татарстан: Архат, Экада 113 , Тулайковская 108, Ульяновская 105, при этом, однородность генетики устойчивости этих сортов не позволяет избежать эпифитотий листовой бурой ржавчины в будущем.

Благодарности: статья подготовлена в рамках государственного задания АААА-А18-118031390148-1.

\section{Список литературы}

1. Сюков В.В. Листовая бурая ржавчина: фитопатологические и селекционногенетические аспекты. - Казань: Из-во Бук, 2016. - 128 с.

2. Morgounov A. Genetic protection of wheat from rusts and development of resistant varieties in Russia and Ukraine / A. Morgounov, I. Ablova, O. Babayants, L. Babayants, L. Bespalova, Z.L. Khudokormov, N. Litvinenko, V. Shamanin, V. Syukov // Euphytica. - 2011. - Vol.179. - P. 297-31.

3. McIntosh R.A. Catalogue of gene symbols for wheat: 2013-2014 supplement / R.A. McIntosh, J. Dubcovsky, W.J. Rogers, C. Morris, R.Appels,X.C. Xia // Komugi websites. $-31 \mathrm{p}$.

4. McIntosh R.A. Catalogue of gene symbols for wheat: 2015-2016 supplement / R.A. McIntosh, J. Dubcovsky, W.J. Rogers, C. Morris, R. Appels, X.C. Xia // Komugi websites. $-18 \mathrm{p}$.

5. McIntosh R.A. Catalogue of gene symbols for wheat: 2017 supplement / R.A. McIntosh, J. Dubcovsky, W.J. Rogers, C. Morris, X.C. Xia // Komugi websites. -20 p.

\section{Источники полевой устойчивости яровой мягкой пшеницы к Puccinia graminis $f$. sp. tritici в условиях Предкамской зоны республики Татарстан}

Асхадуллин Д-р.Ф. ${ }^{1}$, к.с.-х.н., в.н.с., Асхадуллин Д-л.Ф. ${ }^{l}$, к.с.-х.н., в.н.с., Василова Н.3. ${ }^{l}$, к.с.-х.н., в.н.с., Зуев Е.В. ${ }^{2}$, к.с.-х.н., в. н. с, Багавиева Э.3. ${ }^{1}$, к.с.х.н., с.н.с., Тазутдинова М.Р. ${ }^{l}$, н.с., Хусаинова И.И. ${ }^{1}$, м.н.с.

${ }^{1}$ Татарский НИИСХ-ФИЦ КазНЦ РАН, г. Казань, Россия;

${ }^{2}$ ФИЦ ВИГРР им. Н.И. Вавилова, С.-Петербург, Россия.

e-mail: trulik@ya.ru

В республике Татарстан резко возросла вредоносность стеблевой ржавчины пшеницы, скрининг коллекционных образиоввыявил слабо восприимчивые образиы к заболеванию в течении ряда лет. 